\title{
Age and growth of common bream, Abramis brama (L.), caught at Hammam Debagh Reservoir (Guelma, northeast Algeria)
}

\author{
Mohamed Guettaf, Mounira Rachedi, Yassine Gueroui, Aissam Bousbia, Mohamed \\ Amine Chelaghmia, Ammar Maoui
}

Received - 26 April 2019/Accepted - 24 September 2019. Published online: 30 September 2019; $\odot$ Inland Fisheries Institute in Olsztyn, Poland Citation: Guettaf M., Rachedi M., Gueroui Y., Bousbia A., Chelaghmia M.A., Maoui A. 2019 - Age and growth of common bream, Abramis brama (L., 1857), caught at Hammam Debagh Reservoir (Guelma, northeast Algeria) - Fish. Aquat. Life 27: 149-158.

\begin{abstract}
This study was conducted in Hammam Debagh Reservoir located in northeastern Algeria, which was first the subject of fish farming tests in 2001. The species tested included Chinese carp, royal carp, common carp, pikeperch, and common bream. The present work aimed to determine the age and growth of one of the most frequently caught species in the reservoir, common bream, Abramis brama. This information is essential to the knowledge of fish biology, and thereby to solving many of the problems of fish research and development. A sample of 100 common bream, A. brama, was
\end{abstract}

\footnotetext{
M. Guettaf [ $\sqsubseteq]$, Y. Gueroui, A. Bousbia

Département des Sciences de la Nature et de la Vie

Université 8 Mai 1945 Guelma BP 401, Guelma 24000, Algérie

e-mail: guettaf.mohamed@univ-guelma.dz or

abdelyakine23@yahoo.fr; (+213) 772095598

M. Guettaf, A. Bousbia

Laboratoire Biologie, Eau et Environnement (LBEE)

Université 8 Mai 1945 Guelma BP 401, Guelma 24000, Algérie

M. Rachedi

Département des Sciences de la Mer

Université Chadli Bendjedid, El Tarf, Algérie

Y. Gueroui, A. Maoui

Laboratoire Génie Civil et Hydraulique (LGCH)

Université 8 Mai 1945 Guelma BP 401, Guelma 24000, Algérie

\section{A. Chelaghmia}

Laboratoire d'Analyse Industrielle et d'Ingénierie des Matériaux (LIAME), Université 8 Mai 1945 Guelma, BP 401, Guelma 24000, Algérie
}

caught with gillnets over a period of six months from December 2017 to May 2018. The results obtained fit well with the growth model and were similar to those published regarding other environments. Scales from a sample of 50 fish were read under an optical microscope, which permitted identifying five age groups. The value of the overall sex ratio (4.88) revealed a strong imbalance in favor of males throughout the study period. The relationship linking length-weight is of the minor allometry type with $\mathrm{b}<3$.

Keywords: Common bream, age, reservoir, growth, scale

\section{Introduction}

Common bream, Abramis brama (L.), is a benthic freshwater species that is distributed throughout Western and Central Europe and Asia. It was accidentally introduced into the Hammam Debagh Reservoir in 2011 along with another species known as Chinese carp. According to the Directorate of Fisheries and Fishery Resources of the Wilaya of Guelma, bream was among the most abundant fish species in the commercial harvests of 2015 and 2016, and it comprised about $20 \%$ of the catches in the reservoir.

Bream age and growth have been studied by several authors (Goldspink 1981, Kompowski 1982, Lammens 1982, Kangur 1996, Specziár et al. 1997,

\footnotetext{
(c) Copyright by Stanisław Sakowicz Inland Fisheries Institute in Olsztyn.

(C) 2019 Author(s). This is an open access article licensed under the Creative Commons Attribution-NonCommercial-NoDerivs License (http://creativecommons.org/licenses/by-nc-nd/3.0/).
} 


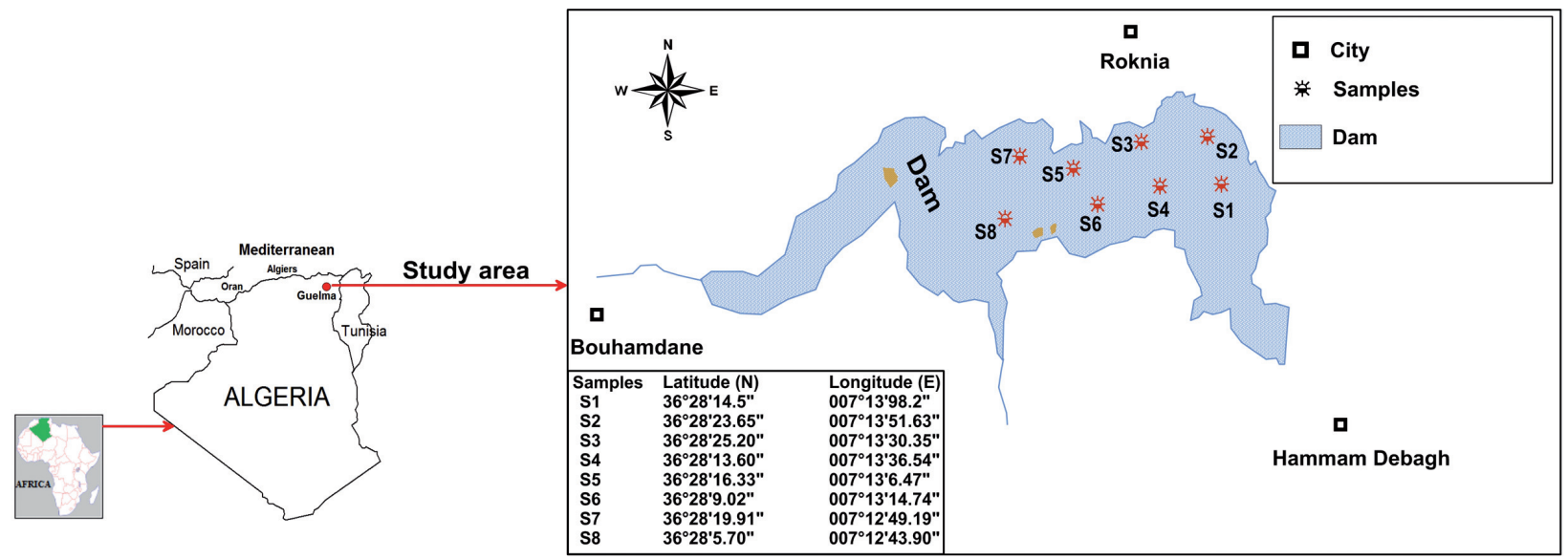

Figure 1. Location of the study area.

Matenova et al. 1998, Tierney et al. 1999, Kakareko 2001, Adakbek et al. 2003, Treer et al. 2003, Žiliukienè and Žiliukas 2011); however, no study has focused on the bream population in Algeria. Živkov et al. (1999) designated four main types of bream length growth: asymptotic standard lengths $(\mathrm{L} \infty)$ up to $60 \mathrm{~cm}$ that is typical for cold, northern water basins and also stocks with a high initial growth rates; a moderate growth rate with $\mathrm{L} \infty$ between 60 and $80 \mathrm{~cm}$; two types with asymptotic values that are too high and are biologically insignificant.

The development of research on rational fisheries management and exploited stock dynamics has led renewed interest in accurate age determination methods (Daget and Le Guen 1975). While Zhang et al. (2016) propose that scales are the only structure that can be used to study common bream growth, and Goldspink (1981) used the operculum to study the growth rates of $A$. brama in three eutrophic lakes in England, otoliths are widely accepted as the most appropriate structure for determining fish age (Phelps et al. 2007, Ma et al. 2011).

This work undertook to study, for the first time, the age, growth, and population conditions of bream in Hammam Debagh Reservoir where no ichthyological research has been done on this species since the reservoir was impounded or even in eastern Algeria.

\section{Study area}

Located in northeastern Algeria at $36^{\circ} 27^{\prime} 41.78^{\prime \prime} \mathrm{N}$, $7^{\circ}$ 14' 12.99" E (Fig. 1) and at an altitude of $720 \mathrm{~m}$, the reservoir is located $3 \mathrm{~km}$ upstream from the town of Hammam Debagh and about $20 \mathrm{~km}$ from the city of Guelma on a site rich in vegetation. The surrounding lands are exclusively agricultural. The reservoir is $430 \mathrm{~m}$ wide from east to west, 2,300 $\mathrm{m}$ long from north to south and is roughly rectangular in shape covering an area of $4.9 \mathrm{~km}^{2}$. The depth ranges, on average, between 65 and $98 \mathrm{~m}$ in the vicinity of the catch tower and begins to decrease irregularly approaching the limit of the upstream zone where it reaches $2 \mathrm{~m}$. The bottom of the reservoir is covered by a thick layer of black mud, which is very thin in some places and rests on a sandy-clay substrate (red and gray clay). It rises from the west east of Hill 530 to Hill 612. The length of the main course of the Wadi Bouhamdane that feeds the reservoir is $99 \mathrm{~km}$. It has a slope of 0.008 (ANRH 2008) and an average altitude of $785 \mathrm{~m}$ (270-1281 m). The density of permanent drainage is $0.53 \mathrm{~km}^{-1}$, while that of temporary drainage is $1.90 \mathrm{~km}^{-1}$. The reservoir has a total capacity of $220 \mathrm{hm}^{3}$ that allows annual regulation of 55 to $60 \mathrm{hm}^{3}$. The watershed covers $1.070 \mathrm{~km}^{2}$ that makes an inter-annual contribution of $69 \mathrm{hm}^{3}$. The maximum flood achieved by the project is $3.500 \mathrm{~m}^{3}$ $\mathrm{s}^{-1}$. The area is not very urbanized, and the local 
population lives in traditional houses and raises cattle and sheep, and there is substantial agriculture, mainly of cereal crops, which occupies $58.1 \%$ of the surface of the basin, while olive trees occupy approximately $8 \%$.

\section{Material and methods}

A total of 100 specimens was caught during the monthly sampling carried out between December 2017 and May 2018 at six sites (Fig. 1) using a trammel net $50 \mathrm{~m}$ long and just over $1 \mathrm{~m}$ high (internal mesh size $10 \mathrm{~cm}$; external mesh size $23 \mathrm{~cm}$ ). The samples obtained were transported to the laboratory and the following parameters were recorded for each individual: total length and standard length (TL and SL; to the nearest $0.1 \mathrm{~cm}$ ), total weight (TW; to the nearest $0.01 \mathrm{~g}$ ), eviscerated weight (EW; to the nearest $0.01 \mathrm{~g}$ ). The sex and maturity stage were identified by macroscopic observations of gonads. Scales of $A$. brama were removed from the area below the pectoral fin, washed, and placed between two glass slides. Then they were photographed with a digital camera coupled with a binocular microscope (Optika Vision Lite 2.1). The von Bertalanffy equation has been used to describe $A$. brama growth (von Bertalanffy 1938):

$$
\mathrm{TL}=\mathrm{L} \infty\left(1-\mathrm{e}^{-\mathrm{k}(\mathrm{t}-\mathrm{t})} 0\right)
$$

where $\mathrm{L} \infty$ is the asymptotic mean length, $\mathrm{k}$ is the growth rate, and $t_{0}$ is the hypothetic age at zero length. For weight growth, the weight-age relationship that was described as linear growth with the von Bertalanffy equation that expresses the evolution of weight as a function of time:

$$
\left.\mathrm{TW}=\mathrm{W} \infty\left(1-\mathrm{e}^{-\mathrm{k}(\mathrm{t}-\mathrm{t}}\right)^{)}\right)^{\mathrm{b}} \text {, }
$$

where TW is the average weight of fish at time t; $\mathrm{W} \infty$ is the maximum mass corresponding to $\mathrm{L} \infty$ (obtained from the relationship $\mathrm{TW}=\mathrm{a} \mathrm{TL}^{\mathrm{b}}$ by replacing TL by $\mathrm{L} \infty: \mathrm{W} \infty=\mathrm{a}(\mathrm{L} \infty)^{\mathrm{b}}$, $\mathrm{b}$ being close to 3 , this curve is a sigmoid that starts from point $\mathrm{t}=\mathrm{t}_{0}$ and is asymptotic at the right $\mathrm{y}=\mathrm{W} \infty$.

The commonly used length-weight relationship by Ricker (1973) was applied: $\mathrm{TW}=\mathrm{a} \mathrm{TL}^{\mathrm{b}}$, where TW is total weight $(\mathrm{g})$, TL is total length $(\mathrm{cm})$, and $\mathrm{a}$ and $\mathrm{b}$ are the constants.

The difference in the length-weight relationship between the sexes was tested with ANCOVA, while the hypothesis of isometric growth was tested with the t-test. The growth performance index (Pauly and Munro 1984) $\varphi=\log k+2 \log L \infty$ was calculated to compare the results obtained in this study with results published elsewhere. FISAT II (Gayanilo et al. 1996) was used to estimate the length-weight relationship and the growth parameters of the von Bertalanffy (1938) equation. The sex ratio was calculated globally as the ratio between the number of males and the number of females $\mathrm{M} / \mathrm{F}$, then it was calculated for each month and by size class.

\section{Results}

\section{Age and growth}

Common bream age was determined according to the number of scale growth streaks, and this permitted us to devise an age-length key. The age of the sampled fish ranged from 2 to 6 years, with the predominance of age groups 2 and 3 constituting $70 \%$ of the catches (Table 1).

There is a very close correlation between the total fish length (TL) and the radius scale (RS): $T L=f(R S)$, which permitted us to relate these two parameters. The equation expressing the linear relationship between the total length (TL) and scale radius (RS) was $\mathrm{TL}=24.83 \mathrm{RS}+24.19(\mathrm{~mm})(\mathrm{r}=0.51 ; \mathrm{P}<0.001)$. The size of the fish at the appearance of the first scales was $24.19 \mathrm{~mm}$. The results of the mean back-calculated lengths for each age in the total population obtained with Lee's formula are summarized in Table 2. The fish measured were divided into size classes at $5 \mathrm{~cm}$ intervals. These data reflect the size distribution at a given age and indicate their extreme values for each age.

Back-calculated lengths were used to calculate the von Bertalanffy parameters of $\mathrm{L} \infty=45.52 \mathrm{~cm}, \mathrm{k}$ $=0.28$, and $t_{0}=-2.67$. The age group $6+(n=2)$ was 
Table 1

Age-length keys of A. brama from the Hammam Debagh Reservoir

\begin{tabular}{|c|c|c|c|c|c|c|}
\hline \multirow[b]{2}{*}{ Size classes $(\mathrm{cm})$} & \multicolumn{6}{|c|}{ Age (years) } \\
\hline & $2+$ & $3+$ & $4+$ & $5+$ & $6+$ & $\mathrm{N}$ \\
\hline $13-18$ & & 1 & & & & 1 \\
\hline $18-23$ & & 2 & & & & 2 \\
\hline $23-28$ & & 10 & 6 & 2 & & 18 \\
\hline $28-33$ & 1 & 3 & 8 & 4 & & 16 \\
\hline $33-38$ & & 2 & 2 & 5 & 1 & 10 \\
\hline $38-43$ & & & 1 & 1 & 1 & 3 \\
\hline $\mathrm{N}$ & 1 & 18 & 17 & 12 & 2 & 50 \\
\hline $\mathrm{n} \%$ & $2 \%$ & $36 \%$ & $34 \%$ & $24 \%$ & $4 \%$ & $100 \%$ \\
\hline Total length (mean (SD)) & 28.5 & $25.95(5.06)$ & $30.01(3.60)$ & $33.29(3.97)$ & $37.25(3.18)$ & $29.59(5.25)$ \\
\hline Eviscerated weight (mean (SD)) & 208 & $199.05(7.75)$ & $224.29(7.28)$ & $245.41(10.43)$ & $417(6.64)$ & $22.76(9.05)$ \\
\hline Total weight (mean (SD)) & 225 & $220.78(8.72)$ & $249.59(7.69)$ & $288.33(13.64)$ & $464(7.35)$ & $256.6(10.66)$ \\
\hline
\end{tabular}

Table 2

Mean (SD) total length (in $\mathrm{cm}$ ) at the appearance of each scale growth arrest ring in the total population of $A$. brama in Hammam Debagh Reservoir

\begin{tabular}{lllllll}
\hline \hline Age & TL1 & TL2 & TL3 & TL4 & TL5 & TL6 \\
\hline \hline $2+(\mathrm{N}=1)$ & 14.83 & 18.31 & & & & \\
$3+(\mathrm{N}=18$ & $14.16(2.97)$ & $19.29(3.81)$ & $24.45(3.64)$ & & & \\
$4+(\mathrm{N}=17)$ & $14.61(3.76)$ & $19.31(3.82)$ & $24.78(4.11)$ & $29.1(3.69)$ & & \\
$5+(\mathrm{N}=12)$ & $14.44(2.41)$ & $19.4(3.03)$ & $22.9(3.21)$ & $28.44(3.92)$ & $31.75(4.34)$ & \\
$6+(\mathrm{N}=2)$ & $14.33(0.7)$ & $21.41(2.98)$ & $27.0(3.51)$ & $34.94(4.91)$ & $39.29(4.74)$ & $40.28(4.74)$ \\
Total length mean (SD) & $14.4(3.07)$ & $19.39(3.49)$ & $24.29(3.72)$ & $29.23(4.02)$ & $32.83(5.01)$ & $40.28(4.74)$ \\
Number of back-calculations & 50 & 50 & 49 & 31 & 14 & 2 \\
\hline \hline
\end{tabular}

not considered in the calculation of the latter. The performance index $(\varphi)$ calculated was 2.76. The asymptotic length calculated from the scales $\left(\mathrm{L} \infty_{>0^{x+q}+\mathrm{I}}=45.52 \mathrm{~cm}\right)$ was perfectly consistent with the maximum length observed in the total population $(\mathrm{TL}=41.5 \mathrm{~cm})$. The parameters of the von Bertalanffy equation calculated for common bream in Hammam Debagh Reservoir were compared with those of previous works as presented in Table 3. According to von Bertalanffy's model, the equation of the linear curve was written $\mathrm{TL}=45.52 \times$ $\left(1^{-\mathrm{e}-0.28(\mathrm{t}+2.67)}\right)$. Figure 2 represents the theoretical total length observed and the corresponding theoretical annual increase.

\section{Length-weight relationship}

The negative allometry for $A$. brama in the study area for combined sexes $(\mathrm{r}=0.83 ; \mathrm{P}<0.001)$ and males $(\mathrm{r}$ $=0.86 ; \mathrm{P}<0.001)$ were observed (Table 4). For females, isometric growth was recorded $(\mathrm{r}=0.90$; $\mathrm{P}<$ 0.001). The slopes (b-values) of the length-weight relationship or the eviscerated size-weight relationship did not differ between the sexes (ANCOVA 
Table 3

Comparison of growth parameters for A. brama in Hamman Debagh Reservoir with those determined by other authors

\begin{tabular}{|c|c|c|c|c|}
\hline Place and source & $\begin{array}{l}\mathrm{t} \\
\text { (year) }\end{array}$ & $\begin{array}{l}\text { Asymptotic stan- } \\
\text { dard length in } \\
\mathrm{cm}(\mathrm{L} \infty)\end{array}$ & $\begin{array}{l}\text { Curvature } \\
\text { parameter (k) }\end{array}$ & $\begin{array}{l}\text { Overall growth } \\
\text { performance }(\Phi)\end{array}$ \\
\hline Hammam Debagh Reservoir (Guettaf et al. 2018) & 6 & 45.52 & 0.28 & 2.76 \\
\hline Croatian Danube (Treer et al. 2003) & 16 & 57.7 & 0.087 & 5.67 \\
\hline Lake Balaton (Specziar et al. 1997) & 10 & 50.1 & 0.083 & 5.34 \\
\hline 103 populations (Živkov et al. 1999) & 10 & 62.3 & 0.0986 & 5.95 \\
\hline Curonian Lagoon (Stankus et al. 2006) & 15 & 71.6 & 0.576 & 2.591 \\
\hline Lake Rubikiai (Žiliukienè et al. 2011) & 13 & 65.7 & 0.085 & 2.565 \\
\hline Average lengths reference (Hartvich and Kubečka 1989) & 11 & 44.5 & 0.153 & 5.71 \\
\hline
\end{tabular}

covariance analysis, $\mathrm{F}=2.43$ and $\mathrm{F}=2.45$ respectively, $\mathrm{P}>0.05)$.

\section{Weight growth}

The weight growth equation for both sexes was $\mathrm{W}=6106.986\left[1-\mathrm{e}^{-0.28(\mathrm{t}+2.67)}\right]^{2.463}$. The asymptotic weight in the total population of $\mathrm{W} \infty=$ $6106.986 \mathrm{~g}$ was greater than the maximum observed weight $(\mathrm{We}=527 \mathrm{~g})$.

\section{Sex ratio}

Of the100 individuals examined, 83 were male and 17 were female, which represents a strong, significant imbalance in favor of the males. The ratio of males to females was 4.88. Statistical tests showed that the difference between males and females was highly significant. Except in February, males were more numerous and dominant than females throughout the study period, especially in April and May, the months that coincided with the spawning period (Table 5). It was difficult to determine whether the difference between males and females was because of the migration of females to the bottom, i.e., to the spawning grounds of the reservoir, or to the selectivity of the fishing gear. This could also have resulted from both phenomena.

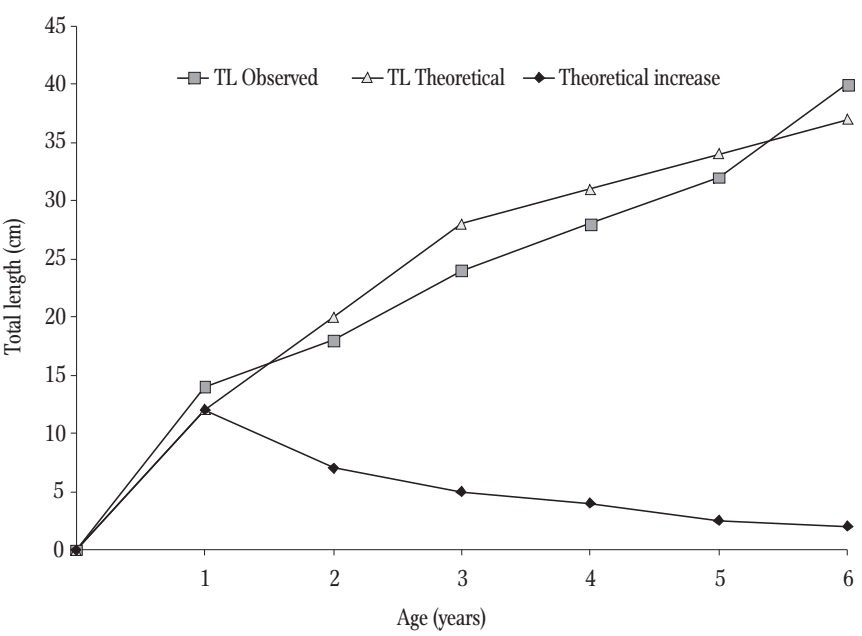

Figure 2. Observed and theoretical linear growth and theoretical annual increase calculated for the total population of $A$. brama in Hammam Debagh Reservoir.

\section{Discussion}

Age determinations are essential fish biology knowledge, and they contribute to solving many problems concerning fish research and development (Carlander 1956, Lagler 1956). It is through the study of fish age and mortality that the importance of various age classes in a population is discovered. This knowledge can be used to make forecasts of the magnitude of possible catches and to suggest what changes should be made to regulations. In this study, 
Table 4

Parameters of the A. brama length-weight relationship in Hammam Debagh Reservoir

\begin{tabular}{llllll}
\hline \hline Sex & $\mathrm{N}$ & $\mathrm{r}$ & Mean $\pm \mathrm{SD}$ & Length-weight relations & Allometry \\
\hline \hline Males & 83 & 0.86 & $236.02 \pm 10.65$ & $\mathrm{TL}=0.05$ EW2.46 & Negative allometry \\
& & & $260.36 \pm 11.78$ & $\mathrm{TL}=0.05$ TW2.45 & \\
Females & \multirow{2}{*}{0.90} & $169.82 \pm 10.05$ & $\mathrm{TL}=0.03$ EW 2.56 & Isometric growth \\
& \multirow{2}{*}{ Total } & \multirow{2}{*}{0.83} & $211.11 \pm 11.71$ & $\mathrm{TL}=0.03$ TW 2.56 & \\
& & $225.61 \pm 10.82$ & $\mathrm{TL}=0.05$ EW 2.46 & \multirow{2}{*}{ Negative allometry } \\
\hline \hline
\end{tabular}

TL - total length, EW - eviscerated weight, TW - total weight

Table 5

Monthly evolution of the sex ratio (SR) of the A. brama population in Hammam Debagh Reservoir

\begin{tabular}{llllll}
\hline \hline Month & Males & Females & SR & $\chi_{\text {obs }}^{2}$ & P-value \\
\hline \hline December & 14 & 1 & 14 & $11.26 \mathrm{~S}$ & 0.00 \\
February & 2 & 5 & 0.4 & $1.28 \mathrm{C}$ & 0.31 \\
March & 28 & 9 & 3.11 & $9.75 \mathrm{~S}$ & 0.00 \\
April & 21 & 1 & 21 & $18.18 \mathrm{~S}$ & 0.00 \\
May & 18 & 1 & 18 & $15.21 \mathrm{~S}$ & 0.00 \\
\hline \hline
\end{tabular}

the scale striations were well marked and spaced, which facilitated reading them microscopically and determining the five age groups (Table 1). The identification of five age groups in the study sample caught indicated that the bream birth date was June 2012, and that these fish had been released into the reservoir as six-month-old juvenile specimens, and similar stocking operations were conducted in 2013, 2014 , and 2015. Since bream generally reaches sexual maturity at the age of four years (Backiel and Zawisza 1968), the first recruitment in reservoir waters was in 2016 followed by a second in 2017 .

In the present study, the fish length at which scales first form that was determined empirically was $24.19 \mathrm{~mm}$ in the Hammam Debagh Reservoir, which was close to the $20 \mathrm{~mm}$ length reported by Vasnetsov et al. (1957) and Kennedy and Fitzmaurice (1968). Fish growth depends on multiple factors that are related to three groups of factors: hereditary, dietary, and environmental (other than food, that include dissolved salts, latitude, insolation, geological nature of the soil, temperature). Temperature, in particular, clearly influenced the rate of food conversion, either as energy for vital life processes or as fish flesh.
Noteworthy among studies that focus on nutritional and growth issues is Kesteven (1946) who calculated the maintenance feed ration (which is ratio of the weight of food consumed daily that ensures the weight of a fish is maintained) at approximately $2 \%$. Marciak (1972) found a positive correlation between growth rates and invertebrate biomass of mud. Stankus (2006) reports that the growth rate of $A$. brama is related to latitude and compared growth rates of $A$. brama in different water bodies and found that growth decreased with increasing latitude. Growth was influenced not only by the geographical location of the water body, but also by the abundance of food. Kakareko (2001) and Stankus (2006) indicated that growth rates of $A$. brama depended on the abundance of benthic organisms.

The growth rates of the bream in the Hammam Debagh Reservoir of $\Phi=2.76$ and $\mathrm{L} \infty=45.52 \mathrm{~cm}$ obtained in the current study were significantly lower than in previous studies (Table 4). Low growth rates could be linked to the high bream density and the scarcity of zoobenthos. Whereas Živkov et al. (1999) report a relatively higher $A$. brama growth rate of $\Phi=$ 5.95 and $\mathrm{L} \infty=62.3 \mathrm{~cm}$, and Treer et al. (2003) also 
report a particularly high $A$. brama growth rate of $\Phi$ $=5.67$ and $\mathrm{L} \infty=57.7 \mathrm{~cm}$ in the Danube in Croatia.

These results indicate that beside benthic organism abundance, many other factors, such as temperature and latitude, influence the growth of the common bream populating the Hammam Debagh Reservoir. Thus, it cannot be assumed that the stock or productivity of the reservoir can be properly estimated based solely on quantitative analyses of benthos or plankton.

Parameters $a$ and $b$ of the length-weight relationship are very sensitive to the number of monthly samples and the size composition of each sample (Fréon 1988). Thus, the relationship between length and weight in both sexes was very well correlated at $r=0.90$ for females (Fig. 3) nad $r$ $=0.86$ for males (Fig. 4). Figure 5 indicates that regardless of the size of the species, the scatterplot is not dispersed, which suggests that the length-weight relationship is governed by the same correlation for all sizes. The allomeric coefficient value in both sexes combined of $b=2.46$ was lower than values obtained in previous work conducted in different regions, for example, for the same bream species $b=2.884$ (Dauba and Biró 1992) in Hungary, $b=3.020$ (Kompowski 1982) in Poland, $b=3.175$ (Verreycken et al. 2011) in Belgium, $b=$ 3.250 (Tarkan et al. 2006) in Turkey, and $b=$ 3.207 (Huo et al. 2011) in China. This minor allometry indicates that growth in length was faster than growth in weight. The rate of weight increase also decreased gradually with age (Fig. 6). It is important during the first years of fish life when bream gains weight more quickly.

In studies of population dynamics, it is always necessary to know the sex ratio since it is indeed the number of females in the population that determines the number of future recruits. Up to four periods with specific sex ratios can generally be distinguished in breeding populations (Živkov 1980, Yankov and Zivkov 1988). Males dominate the youngest age groups (period A) because they mature earlier. The next period (B) has balanced sex ratios, while females dominate the older age groups (period C) because of their longer life cycle. There are only females

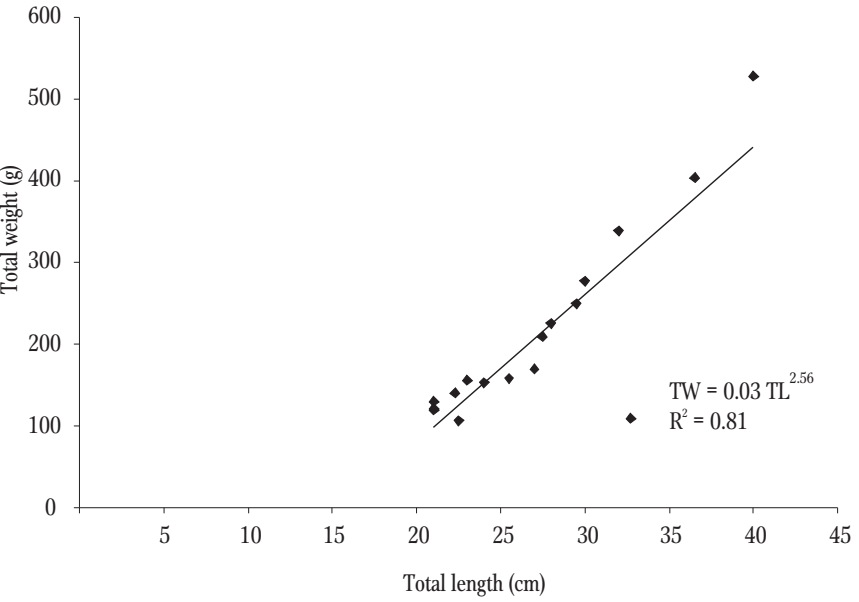

Figure 3. Standard length-weight relationship (a) and total length-weight relationship (b) of A. brama females in Hammam Debagh Reservoir.

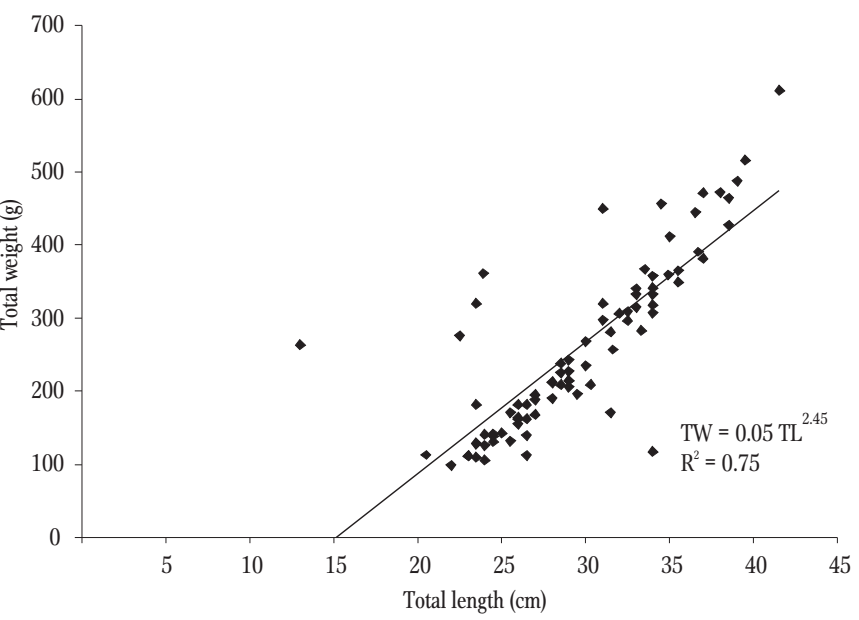

Figure 4. Standard length-weight relationship (a) and total length-weight relationship (b) of A. brama males in Hammam Debagh Reservoir.

in the fourth period (D). The occurrence and duration of the four periods depend on population growth rates and age at first maturity. In this study, our results indicated that there was a strong imbalance in favor of males in the sex ratio of the Hammam Debagh Reservoir common bream population throughout the study period except in February when females dominated (Table 5). So period A dominated and included the age groups caught (2-6 years). Indeed, the geographical distribution of individuals could have been related to hydrological conditions, plankton composition and abundance, 


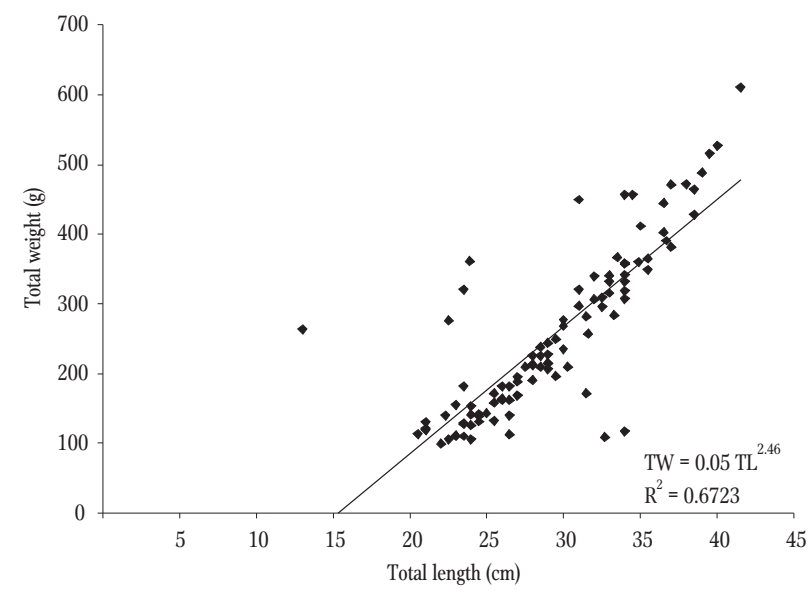

Figure 5. Standard length-weight relationship (a) and total length-weight relationship (b) in both sexes of A. brama in Hammam Debagh Reservoir.

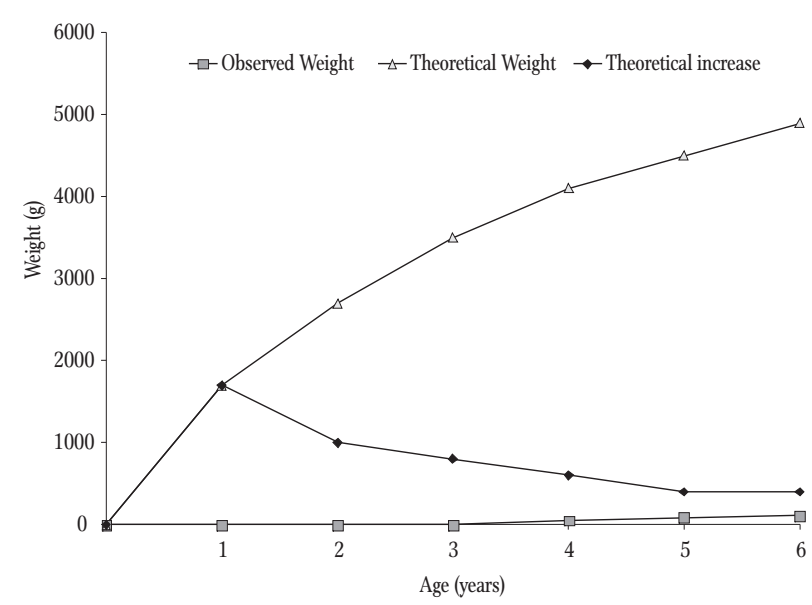

Figure 6. Observed and theoretical weight growth and theoretical annual increase calculated for the total population of $A$. brama in Hammam Debagh Reservoir.

and the migratory nature of common bream (Fréon 1988). Other factors could have also influenced changes in demographic structure, such as the first period of sexual maturity, which could have occured later and lasted longer. Males dominate most bream populations (Table 6) and sometimes consistently, as was the case in Hammam Debagh Reservoir where the number of males was 4.88 times greater than that of females, and they can be from 1.2 to 8.5 times more numerous than females (Karakumskoe Reservoir, Sokolova 1990, Rimov Reservoir, Kubečka 1990, Lake Kotokel, Kupchinskii 1984). Some authors explain this strong sex ratio imbalance by the fact that males stay longer at spawning sites (Kupchinski 1984).

\section{Conclusions}

In addition to changes in its original habitat, the large spatial and temporal variations of various natural biotic and abiotic factors had a great impact on the growth rate of the common bream in Hammam Debagh Reservoir.

Age estimations using growth arrest rings facilitated distinguishing 5 age groups from 2 to 6 years; the one-year-old individuals escaped the fishing gear because of their small size.

The values of the parameters of the Von Bertalanffy linear growth model, and the overall growth performance index $(\Phi)$ calculated in this study were relatively low compared to results obtained in previous work in different regions of Europe and Asia. Despite this, Von Bertalanffy's model was perfectly applicable to the growth of A. brama from the Hammam Debagh Reservoir. The asymptotic length obtained was close to the size of the largest specimen caught.

Allometry coefficient $b$ values that express the relative shape of a fish's body, was less than 3 , so the ANCOVA covariance analysis showed that there was no significant difference between the two sexes. This minor allometry indicates that growth in length was faster than growth in weight. The asymptotic weight obtained was greater than the weight of the largest specimen caught.

Although there is a lack of information on the ichthyofauna of the Hammam Debagh Reservoir, we believe that the relatively low growth rate of common bream in this area can be explained by the difference in temperature and the limited food supply. Such information suggests there are good conditions, but this must be confirmed by detailed research.

Author contributions. M.R. performed the scale analysis under the microscope for age determination, Y.G. contributed to sampling and data processing, A.B. processed the statistical analysis, M.A.C. carried out the 
Table 6

Sex-ratio (SR) variations according to A. brama size in Hammam Debagh Reservoir

\begin{tabular}{llllll}
\hline \hline Size classes & Males & Females & SR & $\chi_{\text {obs }}^{2}$ & P-value \\
\hline \hline $13-18$ & 1 & 0 & - & - & - \\
$18-23$ & 4 & 6 & 0.66 & $0.4 \mathrm{C}$ & 0.33 \\
$23-28$ & 20 & 4 & 5 & $10.66 \mathrm{~S}$ & 0.00 \\
$28-33$ & 27 & 5 & 5.4 & $15.12 \mathrm{~S}$ & 0.00 \\
$33-38$ & 21 & 1 & 21 & $18.18 \mathrm{~S}$ & 0.00 \\
$38-43$ & 6 & 1 & 6 & $3.57 \mathrm{C}$ & 0.07 \\
\hline \hline
\end{tabular}

translation from French to English, A.M. was involved in planning and supervised the work. All authors discussed the results and contributed to the final manuscript.

\section{ORCID ID:}

Mohamed Guettaf. (D https://orcid.org/ 0000-0003-0767-0659

Yassine Gueroui. (D) https://orcid.org/ 0000-0002-3097-8857

Ammar Maoui. (D) https://orcid.org/ 0000-0002-2753-311X

\section{References}

Adakbek K.J., Liu J., Chen Q.Y. 2003 - Studies on the biology and exploitation of Abramis brama Berg in the Ulungur Lake - J. Shanghai Fish. Univ. 112: 366-370.

ANRH 2008 - Agence Nationale des Ressources Hydrauliques - Etude générale des crues du Nord de l'Algérie, Modélisation des débits de crue, Juillet 2008, 73 p.

Backiel T., Zawisza J. 1968 - Synopsis of biological data on the bream Abramis brama (Linnaeus, 1758) - FAO Fisheries Synopsis, 36: 1-122.

Bertalanffy L. von 1938 - A quantitative theory of organic growth (inquiries on growth laws. II) - Human Biol. 10: 181-213.

Carlander K.D. 1956 - Fish growth rate studies: techniques and role in surveys and management - In: Transaction of the Twenty-First North American Wildlife Conference, 26: 262-274.

Daget J., Le Guen J.C. 1975 - Les critčres d'âge chez les poissons - In : Problčmes d'écologie: la démographie des populations de Vertébrés (Eds) M. Lamotte, F. Bourličre, Masson, Paris : 253-289.

Dauba F., Biró P. 1992 - Growth of bream, Abramis brama L., in two outside basins of different trophic state of Lake Balaton - Int. Rev. ges. Hydrobiol. Hydrogr. 77: 225-235.

Fréon P. 1988 - Réponses et adaptations des stocks de Clupéidés d'Afrique de l'Ouest ŕ la variabilité du milieu et de l'exploitation - Etudes et Thčses. ORSTOM Editions, p. 287.

Gayanilo Jr. F.C., Sparre P., Pauly D. 1996 - The FAO-ICLARM stock assessment tools (FiSAT) user's guide - FAO Computerized Information Series (Fisheries), 8: 1-126.

Goldspink C.R. 1981 - A note on the growth - rate and year class strength of bream, Abramis brama (L.), in three eutrophic lakes, England - J. Fish Biol. 19: 665-673.

Hartvich P., Kubečka J. 1989 - Evaluation of fish growth by the method of increment differences - Živoč. Vyr. 34: 917-924.

Huo T.B., Yuan M.Y., Jiang Z.F. 2011 - Length-weight relationships of 23 fish species from the Ergis River in Xingjiang, China - J. Appl. Ichthyol. 27: 937-938.

Kakareko T. 2001 - The diet, growth and condition of common bream, Abramis brama (L.) in Włocławek Reservoir - Acta Ichthyol. Piscat. 31: 37-57.

Kangur P. 1996 - On the biology of bream, Abramis brama (L.) in Lake Peipsi in 1994 - Hydrobiologia 338: 173-177.

Kennedy M., Fitzmaurice P. 1968 - The biology of the bream Abramis brama (L.) in Irish waters - Proc. R. Irish Acad. Sci. 67: 95-157.

Kesteven G.L. 1946 - An examination of certain aspects of the methodology and theory of fisheries biology. (New Haven, Bingham Oceanogr. Lab., Mimeographed, 211 p.).

Kompowski A. 1982 - On some aspects of biology of bream, Abramis brama (L., 1758) inhabiting the River Regalica and Lake Dąbie - Acta Ichthyol. Piscat. 12: 3-25.

Kubečka J. 1990 - Age composition, growth and reproduction of the roach (Rutilus rutilus) and bream (Abramis brama) of the Římov Reservoir - Jihočeské museum v Českých Budějovicích 30 (Suppl. 2): 94-100 (in Czech).

Kupchinskii B.S. 1984 - Ekologo-morfologicheskava leshcha Abramis brama orientalis berg (Cyprinidae) ozera Kotokel (Zabaykale) - Vopr. Ikhtiologii. 24: 585-586 (in Russian).

Lagler K.F. 1956 - Freshwater Fishery Biology - W.C. Brown Company Publishers, Dubuque, Iowa, p. 420. 
Lammens E.H.R.R. 1982 - Growth, condition and gonad development of bream (Abramis brama L.) in relation to its feeding conditions in Tjeukemeer - Hydrobiologia 95: 311-320.

Ma B., Xie C., Huo B., Yang X., Li P. 2011 - Age validation, and comparison of otolith, vertebra and opercular bone for estimating age of Schizothorax o'connori in the Yarlung Tsangpo River, Tibet - Environ. Biol. Fish. 90: 159-169.

Marciak Z. 1972 - Relationship of limnological features to growth of bream (Abramis brama L.) and its catches in Polish lakes - Verh. Int. Ver. Theor. Angew. Limnol. 18: 1182-1189.

Matenova V., Kubecka J., Matena J., Seda J. 1998 - Growth rate of the common bream in lowland European reservoirs with different fish density - Int. Rev. Hydrobiol. 83: 585-590.

Pauly D., Munro J.L. 1984 - Once more on the comparison of growth in fish and invertebrates - Fishbyte 2: 1-21.

Phelps Q.E., Edwards K.R., Willis K. 2007 - Precision of five structures for estimating age of common carp - N. Am. J. Fish. Manage. 27: 103-105.

Ricker W.E. 1973 - Linear regressions in fishery research - J. Fish. Board Can. 30: 409-434.

Sokolova E.L. 1990 - On some indicators of the growth and reproduction of bream in Karakuni Reservoir - Vopr. Ichtiol. 30: 1012-1015 (in Russian).

Specziár A., Tölg L., Bíró P. 1997 - Feeding strategy and growth of cyprinids in the littoral zone of Lake Balaton J. Fish Biol. 51: 1109-1124.

Stankus S. 2006 - Growth parameters of bream (Abramis brama L.) in the Curonian Lagoon, Lithuania - Acta Zool. Lituanica 16: 293-302.

Tarkan A.S., Gaygusuz Ö., Acıpınar H., Gürsoy Ç., Özuluğ M. 2006 - Length-weight relationship of fishes from the
Marmara region (NW - Turkey) - J. Appl. Ichthyol. 22: 271-273.

Tierney D., Donnelly R.E., Caffrey J.M. 1999 - Growth of bream, Abramis brama (L.) in Irish canals and implications for management - Fisheries Manag. Ecol. 6: 487-498.

Treer T., Opacak A., Anicic I., Safner R., Piria M., Odak T. 2003 - Growth of bream, Abramis brama, in the Croatian section of the Danube - Czech J. Anim. Sci. 48: 251-256.

Vasnetsov V.V., Eremeeva E.F., Lange N.O., Dmitrieva E.N., Braginskaya R.Ya. 1957 - Developmental stages of commercial fishes of Volga and Don - Abramis brama, Cyprinus carpio, Rutilus rutilus caspicus, Rutilus rutilus heckeli and Lucioperca lucioperca - Tr. Inst. Morfol. Zhivotn. Akad. Nauk SSSR, 16:7-76 (in Russian).

Verreycken H., Van Thuyne G., Belpaire C. 2011 Length-weight relationships of 40 freshwater fish species from two decades of monitoring in Flanders (Belgium) J. Appl. Ichthyol. 27: 1416-1421.

Yankov Y., Zivkov M. 1988 - Maturation and size and sexual structures of the populations of brown trout (Salmo trutta $m$. fario L.) in the main trout-inhabited rivers in Bulgaria - Hydrobiology 32: 68-84 (in Bulgarian).

Zhang Z.M., Xie C.X., Ding H.P., Liu C.J., Ma X.F., Cai L.G. 2016 - Age and growth of bream Abramis brama (Linnaeus, 1758) in the downstream section of Irtysh River in China - J. Appl. Ichthyol. 32: 105-109.

Žiliukienè V., Žiliukas V. 2011 - Growth rate of freshwater bream (Abramis brama (L.)) in Lake Rubikiai (Lithuania) - Acta Zool. Lituanica, 21: 3-9.

Živkov M. 1980 - Numerical dynamics of fish populations in the Batak Dam. V. Maturity and sex ratio - Hydrobiology 12: 49-62 (in Bulgarian).

Živkov M.T., Trichkova T.A., Raikova-Petrova G.N. 1999 Biological reasons for the unsuitability of growth parameters and indices for comparing fish growth - Environ. Biol. Fish. 54: 67-76. 